BENM 2021

International Scientific and Practical Conference "Biotechnology, Ecology, Nature Management"

\title{
ECOLOGICAL AND ECONOMIC ASPECTS OF STATE REGULATION OF LAND RESOURCES USE
}

\author{
Gaidarenko L. V. (a)*, Kapitsa G. P. (b), Lyubovskaya N. M. (c) \\ *Corresponding author
}

(a) K.G. Razumovsky Moscow State University of Technologies and Management (the First Cossack University), 73, Zemlyanoy Val str., Moscow, Russia, gaydarenkolv@mgutm.ru

(b) K.G. Razumovsky Moscow State University of Technologies and Management (the First Cossack University), 73, Zemlyanoy Val str., Moscow, Russia

(c) K.G. Razumovsky Moscow State University of Technologies and Management (the First Cossack University), 73, Zemlyanoy Val str., Moscow, Russia

\begin{abstract}
the study examines the theoretical and practical aspects of state regulation of the rational use of land resources in the context of ecological and economic development. The author substantiates the relevance of building a qualitative mechanism of state regulation of the rational use of land resources, considers the main elements of legal regulation of the use of land resources, analyzes complex indicators of the effectiveness of state regulation of the use of land resources in the Kursk region, highlights the key vectors of optimization of state regulation of the use of land resources. The work focuses on the need to use an integrated approach to the formation of both national and regional mechanisms for sustainable agriculture, including in the context of the country's food security. A fundamental role in solving this problem should belong to state policy and the accentuated influence of regional authorities, taking into account the territorial specifics. The results of research and analytical diagnostics show the indisputable relevance of the development and implementation of effective tools at the state level, contributing to the growth of the rational use of national land potential. The use of the tools proposed by the author will help to increase the efficiency of the use of land resources in the Kursk region.
\end{abstract}

2672-8575 ㄷ 2022 Published by European Publisher.

Keywords: Environmental and economic efficiency, land resources, rational land use, state regulation 


\section{Introduction}

The relevance of the research topic is due to the role and importance of land resources in the national economic system, which requires an increase in the efficiency of the existing mechanism of state regulation of their use. Rational use of the available land potential is the basis for ensuring the required level of national security, which is especially important in the context of existing geopolitical challenges and macroeconomic risks. The key component of the entire mechanism for the use of land resources is the state policy, which should be aimed at ensuring the productivity, environmental safety and rationality of consumption of the country's land potential within the framework of the current socio-economic formation, taking into account the imperatives of the current legal field. In the structure of state policy, both socio-economic and administrative-legal instruments are used, which are aimed at maximizing the efficiency of the use of land resources. The earth is a unique and limited natural resource that requires careful attitude and maximum rationality of consumption, the potential it forms. In the context of the foregoing, it is important not only to achieve the productive productivity of land resources, but also to competently distribute the land in space, taking into account the forms of ownership and the estimated value. In this regard, the current patterns of functioning of the system of spatial planning and land turnover need to be adjusted.

\section{Problem Statement}

The study of the results of scientific works in the context of the problems under consideration allows us to conclude that state regulation of the use of land resources should pursue two main strategic goals, which are associated with the efficiency and rationality of the consumption of the potential of this resource. The turbulence of the conjunctural factors of the functioning of the socio-economic space of the Russian Federation requires constant monitoring of the current level of efficiency in the use of land resources in order to develop and adapt more effective mechanisms and tools aimed at increasing it. The scale of the country's territory obliges the use of an individual approach to the development of directions of state policy in the field of land resources use, taking into account the climatic and socio-economic specifics of each region.

\section{Purpose of the Study}

The purpose of the work is to clarify the theoretical foundations and consider the practical aspects of state regulation of the rational use of land resources. Achievement of this goal occurs as a result of solving the following list of tasks:

- to substantiate the relevance of building a high-quality mechanism for state regulation of the rational use of land resources;

- to consider the main elements of legal regulation of the use of land resources;

- to analyze the complex indicators of the effectiveness of state regulation of the use of land resources in the Kursk region; 
- to highlight the key vectors of optimization of state regulation of the use of land resources in the Kursk region.

\section{Research Methods}

In the process of performing the work, a wide range of research methods were used, the main of which were the methods of generalization and synthesis, scientific abstraction, analytical diagnostics, regulatory and statistical. The application of the normative legal method made it possible to identify the main elements of the legal field of state regulation of the rational use of land resources. The statistical method based on the use of a representative sample observation contributed to the formation of a reliable information base for analytical calculations. The method of generalization and synthesis created the opportunity to accumulate the entire spectrum of scientific results obtained in a single concept, reflecting the relevance, directions, goals, objectives and features of the rationality of using the national land potential. The method of analytical diagnostics made it possible to study a wide range of indicators characterizing the level of efficiency of state regulation of the use of land resources in the Kursk region.

\section{Findings}

Based on the generalization of theoretical and methodological material, the author concludes that state regulation of the use of land resources is a systemic mechanism for the implementation of the functions of government bodies within the framework of the current regulatory and legal framework, the main vectors of which are formed on the basis of the general strategy of socio-economic development of the state and is aimed to achieve the efficiency of economic and economic use of land resources, the rationality of the spatial and territorial distribution of land, the preservation of biological properties, environmental characteristics and natural fertility. As a result, a key component of the entire mechanism for the use of land resources is the state policy, which should be aimed at ensuring the productivity, environmental safety and rationality of consumption of the country's land potential within the framework of the current socio-economic formation, taking into account the imperatives of the current legal field.

The results of the research carried out made it possible to form an objective conclusion about the indisputable importance of land as an element of national welfare and the foundation of the functioning of the main macroeconomic processes. The scale of the issue of the role of land resources has led to the formation of a stable state mechanism for regulating their use, potential consumption and turnover. This mechanism is public in nature and is determined by the laws of the existing political system, socioeconomic formation and socio-cultural aspects of the development of the nation. The implementation of the entire range of instruments for regulating the use of land relations occurs within the framework of state policy in this area.

Generalization of the research results of the presented articles allows us to single out the following elements of the mechanism of state regulation of the use of land resources:

- regulatory legal acts of land legislation;

- a set of functions of public authorities, which are aimed at ensuring the efficiency of use and the legitimacy of the turnover of land resources; 
- the system of state and municipal authorities, which, taking into account their functions and competencies, participate in the processes of regulating the use of land resources.

The main for the formation of the functionality of public authorities in the field of land resources use is the current regulatory framework. The existing legal framework in the country contains a fairly wide list of normative legal acts regulating certain issues of the use and turnover of land resources. The basis of the regulatory framework for land management in the Russian Federation is the Constitution of the Russian Federation (The Constitution of the Russian Federation, 1993). In our country, the issues of constitutional regulation of the use of land resources are allocated to a separate spectrum of principles of state structure. Among the most relevant provisions of the constitutional regulation of land relations, one can single out Article 9 of the Constitution of the Russian Federation, which declares the need for the protection and protection of land as a fundamental basis for the life and activities of peoples living in this territory. When regulating land relations, the issues of land ownership are of particular relevance. Article 36 of the Constitution of the Russian Federation establishes the fact that ownership of land is an inalienable right of citizens and their associations. In this regard, it should be noted that the economic foundations for using the potential of land resources are precisely based on the use of legitimate forms of land ownership, which are of a constitutional nature. In accordance with the provisions of the Constitution of the Russian Federation, the possession and disposal of land resources on the territory of the country is carried out by their owners freely, but on condition that this should not harm the environment, as well as the legitimate interests of other participants in public relations.

The conditions and directions for the use of land resources in economic and economic activities are determined by the norms of the current federal legislation. An important document regulating a wide range of land relations issues is the Land Code of the Russian Federation (Land Code of the Russian Federation, 2001). Key areas of legal regulation by the Land Code are related to the use and protection of land. The deterioration of the general ecological situation in the country also requires the protection of land resources. The main environmental safety standards for the use of land resources are disclosed in the provisions of the Federal Law "On Environmental Protection" dated January 10, 2002 No. 7-FZ (last edition of March 09, 2021) (On environmental protection..., 2002).

Agricultural land is an important element of the country's land resources. The formation of an effective mechanism for the use of agricultural land occurs subject to their legal turnover. The main legislative framework for the legitimate turnover of agricultural land is the Federal Law "On the turnover of agricultural land" dated 24.07.2002 No. 101-FZ (On the turnover of agricultural land, 2002). This regulatory legal act regulates key aspects of the transfer of ownership of agricultural land. In the process of using the land resources of the country are depleted, which can reduce their productivity and even take them out of agricultural use. The Federal Law "On Land Reclamation" dated 01.10.1996 No. 4-FZ (On land reclamation 1996) is aimed at ensuring the safety of the production potential of the country's land resources. A similar vector of legal action is contained in the provisions of the Federal Law "On State Regulation of Ensuring the Fertility of Agricultural Lands" dated July 16, 1998 No. 101-FZ (On state regulation of ensuring the fertility of agricultural lands, 1998). The application of this legislative framework creates the basis for the implementation of organizational and economic measures aimed at preserving and expanding the production potential of the country's land resources. 
An essential direction of state regulation of the use of land resources is the legal support for the application of organizational and economic forms of land ownership. In particular, peasant farms are one of the mass organizational and legal forms of land use. The legal basis for the activities of peasant farms is disclosed in the provisions of the Federal Law "On Peasant (Farming) Economy" dated 06/11/2003 No. 74-FZ (On the peasant (farm) economy, 2003). The implementation of a stimulating mechanism for the efficiency of the use of land resources requires the use of intensive technologies, which is especially important in the agro-industrial complex. In this regard, state policy is aimed at increasing the economic efficiency of the use of agricultural land. The legislative framework for state regulation and stimulation of the intensification of the use of land resources of the corresponding category of land is disclosed in the provisions of the Federal Law "On the Development of Agriculture" dated December 29, 2006 No. 264FZ (On the development of agriculture, 2006). Rational use of land resources is a strategic priority for the development of the state. This vector of the national strategy of the Russian Federation is enshrined in the Order of the Government of the Russian Federation dated 03.03.2012 No. 297-r "On Approval of the Fundamentals of State Policy for the Use of the Land Fund of the Russian Federation for 2012 - 2020" (On approval of the Fundamentals of State Policy.., 2012 ).

Summarizing what has been said, in Figure 1 we present the basic principles and criteria of legal regulation of the use of land resources.

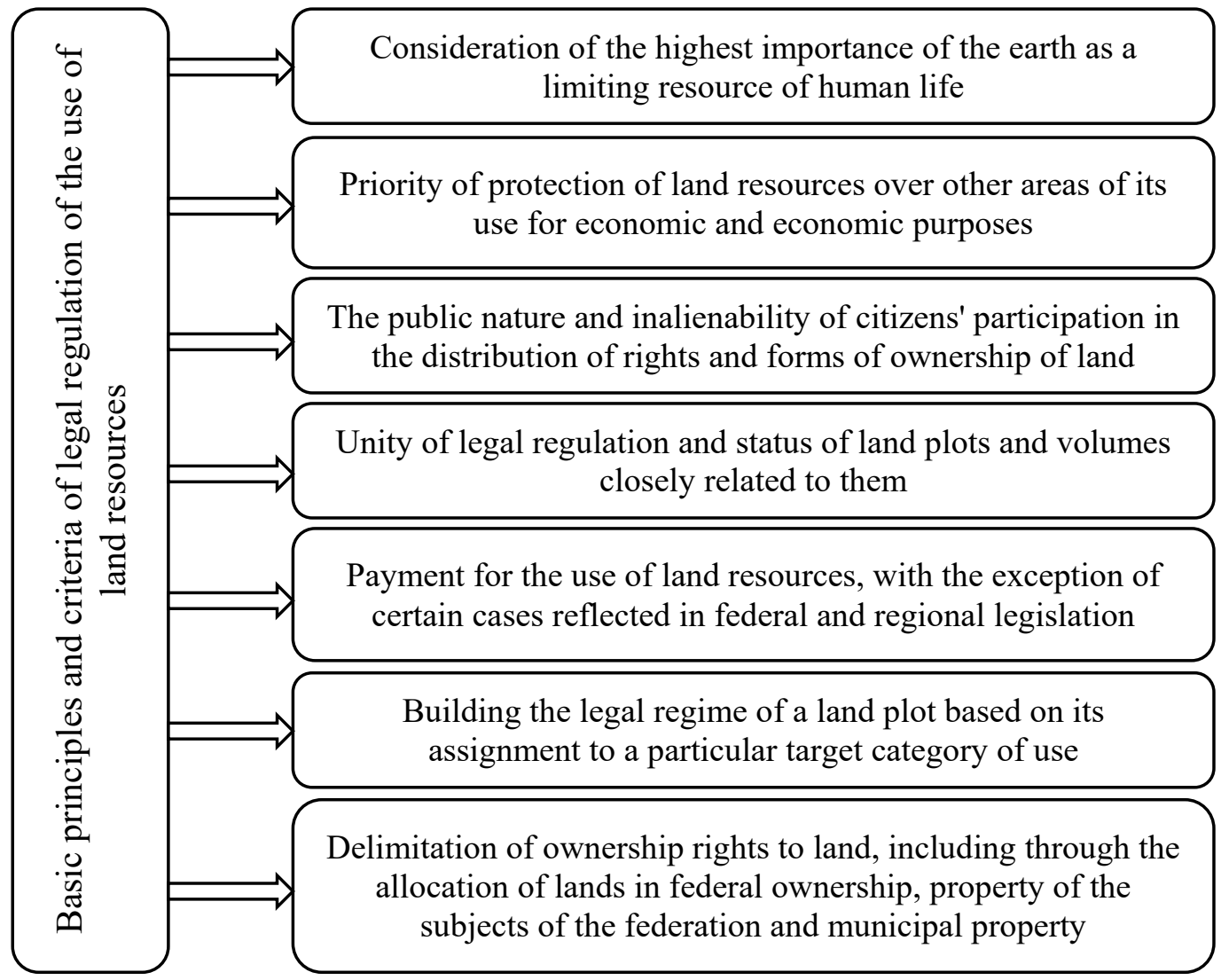

Figure 1. Basic principles and criteria of legal regulation of the use of land resources

Diagnostics of the main indicators of the effectiveness of state regulation of the use of land resources in the Kursk region includes the implementation of a wide range of analytical procedures. In 
table 1, we consider the technological and agrotechnical indicators of the effectiveness of state regulation of the use of land resources in the Kursk region.

Table 1. Technological and agrotechnical indicators of the effectiveness of state regulation of the use of land resources in the Kursk region

\begin{tabular}{|c|c|c|c|c|c|c|c|}
\hline Indicator & 2014 & 2015 & 2016 & 2017 & 2018 & 2019 & 2020 \\
\hline $\begin{array}{l}\text { There are tractors per } 1000 \text { hectares of arable land, } \\
\text { pcs. }\end{array}$ & 2,9 & 2,9 & 3 & 3 & 3 & 3 & 3 \\
\hline Increase, chain, $\%$ & - & 0,00 & 3,45 & 0,00 & 0,00 & 0,00 & 0,00 \\
\hline $\begin{array}{l}\text { Accounted for } 100 \text { tractors for soil treatment } \\
\text { plants, pcs. }\end{array}$ & 139 & 133 & 129 & 127 & 125 & 123 & 121 \\
\hline Increase, chain, $\%$ & - & $-4,32$ & $-3,01$ & $-1,55$ & $-1,57$ & $-1,60$ & $-1,63$ \\
\hline $\begin{array}{c}\text { The value of energy capacity per } 100 \text { hectares of } \\
\text { sown area, thous. Hp }\end{array}$ & 181 & 170 & 175 & 176 & 179 & 193 & 205 \\
\hline Increase, chain, $\%$ & - & $-6,08$ & 2,94 & 0,57 & 1,70 & 7,82 & 6,22 \\
\hline Mineral fertilizers applied per hectare of crops, $\mathrm{kg}$ & 105 & 113 & 139 & 151 & 155 & 162 & 167 \\
\hline Increase, chain, $\%$ & - & 7,62 & 23,01 & 8,63 & 2,65 & 4,52 & 3,09 \\
\hline $\begin{array}{l}\text { Organic fertilizers applied per hectare of crops, } \\
\text { tons }\end{array}$ & 0,4 & 0,4 & 0,5 & 0,6 & 0,5 & 0,6 & 0,6 \\
\hline Increase, chain, $\%$ & - & 0,00 & 25,00 & 20,00 & $-16,67$ & 20,00 & 0,00 \\
\hline Lime materials applied per 1 hectare of crops, tons & 99,5 & 103,4 & 70,9 & 90,2 & 140,2 & 183,8 & 190,7 \\
\hline Increase, chain, $\%$ & - & 3,92 & $-31,43$ & 27,22 & 55,43 & 31,10 & 3,75 \\
\hline
\end{tabular}

Based on the calculations carried out, it can be concluded that the dynamics of technological and agrotechnical indicators of the effectiveness of state regulation of the use of land resources in the Kursk region is of a multidirectional nature. The number of tractors per 1000 hectares of arable land throughout the entire study period has a stable and practically unchanged value. At the same time, the number of installations for tillage per 100 tractors tends to decrease, which is stable throughout the entire time period. In general, in 2020 compared to 2014, the value of this indicator decreased by $12.95 \%$, and its main decrease occurs in 2015 relative to 2014 by $4.32 \%$.

A positive characteristic of the effectiveness of state regulation of the use of land resources in the Kursk region is a steady growth in the value of energy capacities per 100 hectares of sown area. Based on the calculations, it can be noted that in 2020 compared to 2014, the value of energy capacity per 100 hectares of sown area increased by $13.26 \%$. The main increases in this indicator were recorded in 2019 compared to 2018 by $7.82 \%$ and in 2020 compared to 2019 by $6.22 \%$. An increase in this indicator indicates an increase in opportunities for a better use of land resources.

An important aspect of the rational use of land resources is the reproduction of soil fertility and the maintenance of the required level of agrotechnical properties of land resources. Regulation of these issues is carried out by state bodies with the help of direct subsidies to agricultural producers by reimbursing part of the costs of applying mineral and organic fertilizers, as well as measures for liming the soil. The result of these measures of the state policy of regulating the use of land resources was a stable increase in the relative indicators of calcareous soils, as well as the introduction of mineral and organic fertilizers. Based on the calculations, it can be concluded that the amount of applied mineral fertilizers per 1 hectare of crops is steadily increasing throughout the study period. In general, in 2020 compared to 2014, the 
value of this indicator increased by $59.05 \%$, and its key growth occurred in 2016 relative to 2015 by $23.01 \%$.

The amount of applied organic fertilizers per 1 hectare of crops in the Kursk region throughout the study period is generally stable. The decrease in this indicator in 2018 compared to 2017 by $16.67 \%$ was offset by its growth in 2019 relative to 2018 by $20.00 \%$.

In accordance with article 67 of the Land Code of the Russian Federation (2001), state monitoring of lands is part of state environmental monitoring. The results of state monitoring of the state of land resources in the Kursk region are presented in Table 2 (Official site of the Federal State Statistics Service for the Kursk Region, 2021).

Table 2. Main results of state monitoring of the state of land resources in the Kursk region

\begin{tabular}{cccccccc}
\hline Indicator & 2014 & 2015 & 2016 & 2017 & 2018 & 2019 & 2020 \\
\hline Area of eroded land resources, thousand hectares & 95,7 & 102,3 & 107,8 & 110,3 & 115,7 & 117,8 & 121,5 \\
Increase, chain,\% & - & 6,90 & 5,38 & 2,32 & 4,90 & 1,82 & 3,14 \\
$\begin{array}{c}\text { Area of acidified land resources (pH> 5.5), thousand } \\
\text { hectares }\end{array}$ & 30,3 & 31,2 & 29,5 & 30,9 & 31,7 & 30,3 & 32,5 \\
Increase, chain,\% & - & 2,97 & $-5,45$ & 4,75 & 2,59 & $-4,42$ & 7,26 \\
\hline
\end{tabular}

Based on the information base presented in Table 2, it can be concluded that the quality of the state of land resources in the Kursk region has decreased. The noted fact allows us to speak about a decrease in the efficiency of the functioning of mechanisms of state regulation of the use of land resources in the Kursk region in this focus. This conclusion is based on the growth in the area of eroded and acidified land resources. Based on the calculations, it can be concluded that the dynamics of the area of eroded land resources has a steady upward trend within the studied period of time and in 2020, compared to 2014, the value of this indicator increased by $26.96 \%$. The dynamics of the area of acidified land resources is more variable in nature. A significant increase in this indicator is noted in 2020 compared to 2019 by $7.26 \%$.

The author recommends dividing the entire range of tools and directions for optimizing state regulation of the use of land resources in the Kursk region into three main blocks, which are disclosed in Figure 2. 


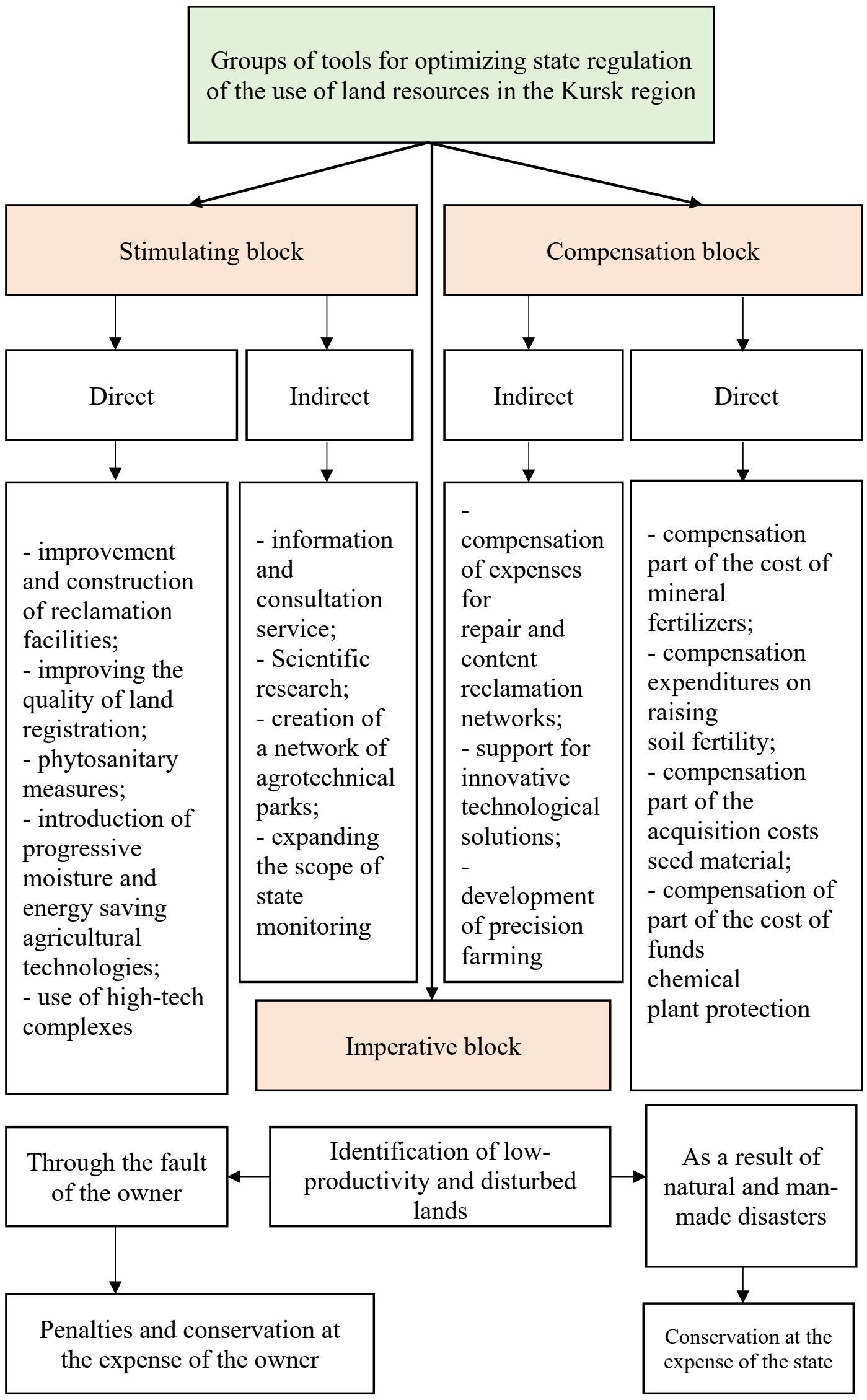

Figure 2. Grouping of tools for optimizing state regulation of the use of land resources in the Kursk region 
We will give a number of explanations to the set of tools for optimizing state regulation of the use of land resources in the Kursk region presented in Figure 2:

- adaptation of the instruments of the imperative block is aimed at preventing the withdrawal of land primarily from agricultural circulation. Within the framework of this block, on the basis of scaling and improving the quality of state supervision, cases of inappropriate and ineffective use of land resources are identified, which serve as grounds for the application of appropriate sanctions;

- the introduction of incentive block instruments is aimed at stimulating owners and users of land resources to introduce more modern and innovative technologies for conducting economic and economic activities. The main focuses of the impact of the tools of this block are support for the development and implementation of innovative technological solutions in agriculture, as well as the introduction of progressive moisture and energy-saving agricultural technologies and the use of high-tech complexes of agricultural machinery;

- using the tools of the compensation block aimed at achieving a high level of rational use of land resources through compensation from the state for key costs in this area. In particular, within the framework of the compensation block, the costs of using elite seeds for the purposes of variety change and renewal, improvement of the varietal and sowing qualities of seed stocks, compensation of part of the cost of mineral fertilizers and chemical plant protection products are compensated.

\section{Conclusion}

The introduction of certain instruments of state regulation of the use of land resources in the Kursk region will be effective only if it is based on the application of a scientifically grounded and systematized methodological base. The criterion for the application of certain instruments of state influence should be the current indicators of the efficiency of the use of land resources. In this regard, it is of key importance to conduct regular and systematic monitoring of the efficiency of the use of land resources. State regulation of the use of land resources is of key importance for achieving the required level of efficiency and rationality of consumption of land potential within the national economic systems. The priority of state regulation in this area is determined by the strategic importance and relevance of the effective use of land resources for the socio-economic development of the country as a whole. The turbulence of the conjunctural factors of the functioning of the socio-economic space of the Russian Federation requires constant monitoring of the current level of efficiency in the use of land resources in order to develop and adapt more effective mechanisms and tools aimed at increasing it. Within the framework of this study, the author proposes three main focuses for improving state regulation of the use of land resources:

- an increase in the intensity of the use of land resources without prejudice to their ecological characteristics;

- increasing the productivity of the use of land resources;

- the introduction of technologies for the "smart" use of land resources, which is especially important in the context of the development of the digital state.

Thus, we can conclude that the use of the tools proposed by the author will contribute to an increase in the efficiency of the use of land resources in the Kursk region. 


\section{References}

Land Code of the Russian Federation (2001). No. 136-FZ SPS ConsultantPlus. URL: http://www.consultant.ru/document/cons_doc_LAW_33773/

Official site of the Federal State Statistics Service for the Kursk Region. (2021).http://kurskstat.gks.ru

On Approval of the Fundamentals of State Policy for the Use of the Land Fund of the Russian Federation for 2012 - 2020. (2012). Order of the Government of the Russian Federation dated 03.03.2012 No. 297-r (as amended on 28.08.2014). SPS ConsultantPlus. http://www.consultant.ru/document/cons_doc_LAW_127154/

On environmental protection. (2002). Federal Law of 10.01.2002 No. 7-FZ (last edition of 09.03.2021). SPS ConsultantPlus. http://www.consultant.ru/document/cons_doc_LAW_34823/

On land reclamation. (1996). Federal Law of 10.01.1996 No. 4-FZ (last edition of 13.05.2021). SPS ConsultantPlus. URL: http://www.consultant.ru/document/cons_doc_LAW_8864/

On state regulation of ensuring the fertility of agricultural land. (1998) Federal Law of July 16, 1998 No. 101-FZ (last edition of November 25, 2020). SPS ConsultantPlus. http://www.consultant.ru/document/cons_doc_LAW_19434/

On the development of agriculture. (2006). Federal Law of December 29, 2006 No. 264-FZ (last revised on October 15, 2020). SPS ConsultantPlus. http://www.consultant.ru/document/cons_doc_LAW_64930/

On the peasant (farm) economy. (2003). Federal Law of 11.06.2003 No. 74-FZ (last edition of 29.12.2020). SPS ConsultantPlus. http://www.consultant.ru/document/cons_doc_LAW_42662/

On the turnover of agricultural land. (2002) Federal Law dated 24.07.2002 No. 101-FZ (last revised on 30.04.2021). SPS ConsultantPlus. http://www.consultant.ru/document/cons_doc_LAW_37816/

The Constitution of the Russian Federation. (1993). SPS ConsultantPlus. http://www.consultant.ru/document/cons_doc_LAW_28399/(date accessed: 13.06.2021). 